\title{
Clinical Outcomes and Risk Factors of Meningitis among Children in Referral Hospital, Ethiopia, 2016: A Retrospective Chart Review
}

\author{
Tilahun Tewabe ${ }^{1}$, Amare Fenta ${ }^{1}$, Abaynesh Tegen ${ }^{1}$, Muluwork Mezgebu', \\ Temesgen Fentie, Tigist Zeleke ${ }^{1}$
}

\section{OPEN ACCESS}

Citation: Tilahun Tewabe, Amare Fenta, Abaynesh Tegen, et al. Clinical Outcomes and Risk Factors of Meningitis among Children in Felege Hiwot Referral Hospital, Amhara Regional State, Ethiopia, 2016: A Retrospective Chart Review. Ethiop J Health Sci. 2018;28 (5):663.

doi:http://dx.doi.org/10.4314/ejhs.v28i5.7

Received: January 6, 2018

Accepted: January 9,2018

Published: September 1, 2018

Copyright: (c) 2018 Tilahun Tewabe, et

al. This is an open access article distributed under the terms of the Creative Commons Attribution License, which permits unrestricted use, distribution, and reproduction in any medium, provided the original author and source are credited.

Funding: Bahir Dar university

Competing Interests: The authors declare that this manuscript was approved by all authors in its form and that no competing interest exists.

Affiliation and Correspondence:

${ }^{1}$ College of medicine and Health

Sciences, Bahir Dar university,

Ethiopia

Email: tilahun.tewabe01@gmail.com

\section{ABSTRACT}

BACKGROUND: Meningitis remains a major cause of mortality and morbidity in patients in many countries of the world including Ethiopia. Information on clinical outcomes of meningitis, susceptibility of the causative microorganism to rationalize treatment and associated risk factors is scare. The objective of this study was to assess the risk factors and clinical outcomes of meningitis among children in Felege Hiwot Referral Hospital, Bahir Dar, Northwest Ethiopia.

METHOD: A retrospective cross sectional study was conducted in Felege Hiwot Referral Hospital from January 2016 to May 2016. Data were checked for completeness, inconsistencies and entered into SPSS for windows version 20.0. Lottery method was used to select charts. One hundred seventy-nine pediatric patient files were used in the study.

RESULT: About 15\% children with meningitis developed poor outcomes: developed complication, referred to higher facility, died and left against medical advice. In this study, season of admission [AOR $=5(1.191,20.991)]$, immunization status $[A O R=20.912$ $(3.325,131.502)]$, clinical presentations $[A O R=8.779$ (1.599, 48.192)] and corticosteroid administration [AOR $=8.215$ (1.220, 55.328)] were the determinant factors for clinical outcome of meningitis.

CONCLUSION: In this study, about 15\% of children with meningitis developed poor outcomes. The determinant factors for poor outcome of meningitis were: season of admission, immunization status, clinical presentations and corticoid administration. Creating community awareness about risk factors of meningitis, early diagnosis and treatment of cases, improving vaccination coverage and use of corticosteroids are recommended to improve the clinical outcome of children affected with meningitis.

KEYWORDS: Clinical outcomes, meningitis, risk factors, children, Felege Hiwot Referral Hospital, Amhara Regional State, Ethiopia 


\section{INTRODUCTION}

Meningitis is one of the most severe diseases accounting for numerous deaths per year. Fatality rate due to meningitis remains high, which is between $2 \%$ and $30 \%$. Long term complications like epilepsy, mental retardation and sensory neural deafness are observed in 10\%-20\% cases $(1,2)$.

Meningitis is a major public health problem needing timely diagnosis, appropriate treatment, prevention and control. The region in SubSaharan Africa, including Ethiopia, is known as the "meningitis belt" because of the high prevalence of meningitis in the area $(2,3)$.

Meningitis in children takes the form of sporadic cases with a rate of $1.5 / 100,000$ and $20 / 100,000$ population in the developed and developing countries, respectively. A minimum of 890,000 cases are estimated to occur per year. Among them, 160,000 and 135,000 are disabling and fatal cases, respectively (4).

Any delay in the initiation of treatment could be fatal. However, antibiotics are often administered before the laboratory results of CSF culture and sensitivity (5).--However, there is limited information available on the risks factors and clinical outcomes of meningitis (6). Therefore, the aim of this study was to identify the risk factors and clinical outcomes of meningitis among children admitted with meningitis to Felege Hiwot Referral hospital, Bahir Dar, Ethiopia.

\section{METHODS AND MATERIALS}

A retrospective chart review study was conducted in Felege Hiwot Referral Hospital (FHRH) by reviewing records of children treated in this hospital from January 2016 to May 2016. FHRH is located in Bahir Dar city, Amhara Regional State, Northwest Ethiopia. Bahir Dar city is located approximately $578 \mathrm{~km}$ northwest of Addis Ababa. Approximately, 26,870 inpatients and 217,251 outpatients are served in the hospital annually. Out of them, 22,100 were children. The total number of admission due to meningitis in pediatrics ward was 282 per year.
Sample size of this study was determined based on single population proportion formula by considering: $5 \%$ margin of error, $50 \%$ prevalence and $95 \%$ confidence interval. After considering $10 \%$ non-response rate and correction formula, the final sample size became 179. Patient records were selected from patient registration books by using simple random sampling technique i.e., lottery method.

Measurement: Patient charts from the age of one month to 15 years admitted due to meningitis were used to collect the data. The data was collected by using structured checklists. Checklists were prepared by reviewing different researches done on similar areas (7-10).

Two nurses with bachelor degree qualification and one supervisor with masters degree were assigned for the data collection process. Before the actual data collection started, a one day training was given for data collectors and the supervisor on how to collect and record data appropriately.

Data analysis: The data obtained from records were coded, filtered and entered into EPI Info version 3.5.3, then transferred to SPSS Version 16 for analysis. To identify factors associated with clinical outcome of meningitis, first bivariate analysis was done to each independent variable with the outcome variable. Those variables which were associated with neonatal mortality were included in multivariate analysis. The strength of association was determined using odds ratio and $95 \%$ confidence level. Statistical significance was set at $\mathrm{P}$ value of $<0.05$.

Ethics: Ethical clearance was obtained from Bahir Dar University College of Medicine and Health Science, Department of Nursing. Confidentiality of information was maintained by omitting the patient names and addresses from the checklist.

\section{RESULTS}

Risk factors for meningitis: One hundred seventy-nine pediatric files were studied. Of the total, 98(54.7\%) were females and 62(34.6\%) were between age of 5-15years. From all, $40(65.6 \%)$ mothers of children were not educated, and $26(45.6 \%)$ of them were employed. Regarding

DOI: http://dx.doi.org/10.4314/ejhs.v28i5.7 
immunization status, 88(49.2\%) were completed. urinary tract infections (UTI) before admission, There was no history of anti-meningitis given to $17(9.5 \%)$ were malnourished and ten (5.6\%) were all of them. Two (1.1\%) of them had history of on immunosuppressive agents (Table1).

Table 1: Risk factors for meningitis patients who were admitted in FHRH, from July 2014-June 2015, Bahir Dar, Ethiopia, $2016(\mathrm{n}=179)$.

\begin{tabular}{|c|c|c|c|}
\hline Variables & & Frequency & Percent \\
\hline \multirow[t]{4}{*}{ Age } & 1month -1year & 38 & 21.2 \\
\hline & $1-2$ years & 41 & 22.9 \\
\hline & $2-5$ years & 38 & 21.2 \\
\hline & $5-15$ years & 62 & 34.6 \\
\hline \multirow[t]{2}{*}{ Sex } & Male & 81 & 45.3 \\
\hline & Female & 98 & 54.8 \\
\hline \multirow[t]{2}{*}{ Maternal education $(n=61)$} & Educated & 21 & 34.4 \\
\hline & Non educated & 40 & 65.6 \\
\hline \multirow{4}{*}{ Maternal occupation $(n=57)$} & House wife & 25 & 43.9 \\
\hline & Employed & 26 & 45.6 \\
\hline & Merchant & 5 & 10.5 \\
\hline & Urban & 120 & 67 \\
\hline \multirow[t]{3}{*}{ Residence } & Rural & 59 & 33 \\
\hline & Winter & 48 & 26.8 \\
\hline & Spring & 49 & 27.4 \\
\hline \multirow[t]{3}{*}{ Season of admission } & Summer & 54 & 30.2 \\
\hline & Autumn & 28 & 15.6 \\
\hline & Yes & 2 & 1.9 \\
\hline use of anti fungal( $n=102)$ & No & 100 & 98.1 \\
\hline Child immunization & Completed & 88 & 66.2 \\
\hline \multirow[t]{3}{*}{$\operatorname{status}(\mathrm{n}=81)$} & Non started & 14 & 10.5 \\
\hline & Incomplete & 2 & 1.5 \\
\hline & Up-to-date & 29 & 21.8 \\
\hline \multirow[t]{2}{*}{ Previous History of UTI(n=69) } & Yes & 2 & 2.9 \\
\hline & No & 67 & 97.1 \\
\hline \multirow[t]{2}{*}{ Nutritional status of child(n=94) } & Malnourished & 17 & 18 \\
\hline & Well nourished & 77 & 82 \\
\hline Use of corticosteroids & Yes & 78 & 43.6 \\
\hline $\operatorname{drugs}(n=168)$ & No & 101 & 56.4 \\
\hline \multirow[t]{2}{*}{ Co infection with HIV/AIDS } & Yes & 8 & 4.5 \\
\hline & No & 171 & 95.5 \\
\hline \multirow[t]{2}{*}{ Co infection with TB } & Yes & 4 & 2.2 \\
\hline & No & 175 & 97.8 \\
\hline \multirow[t]{2}{*}{ Co infection with malaria } & Yes & 2 & 1.1 \\
\hline & No & 177 & 98.9 \\
\hline
\end{tabular}

DOI: http://dx.doi.org/10.4314/ejhs.v28i5.7 
Table 2: Clinical presentations of meningitis patients who were admitted in FHRH, from July 2014-June 2015, Bahir Dar, Ethiopia, 2016 (n=179).

\begin{tabular}{|c|c|c|c|}
\hline Variables & Clinical features & Frequency & Percent \\
\hline \multirow[t]{2}{*}{ Chief compliant at admission } & Worse & 58 & 32.4 \\
\hline & Better & 121 & 67.6 \\
\hline \multirow[t]{4}{*}{ Duration of onset of illness } & $<1$ day & 34 & 19 \\
\hline & 1-2days & 59 & 33 \\
\hline & 3-7days & 64 & 35.8 \\
\hline & $>7$ days & 22 & 12.3 \\
\hline \multirow[t]{2}{*}{ Fever } & Yes & 158 & 93.1 \\
\hline & no & 21 & 11.7 \\
\hline \multirow{4}{*}{$\begin{array}{l}\text { Level of temperature at } \\
\text { admission }(160)\end{array}$} & $35.5-37.5$ & 11 & 6.9 \\
\hline & $37.5-38$ & 45 & 28.1 \\
\hline & $38-40$ & 101 & 63.1 \\
\hline & $>40$ & 3 & 1.9 \\
\hline \multirow[t]{2}{*}{ Brudinski and kerning signs } & Positive & 55 & 30.7 \\
\hline & negative & 124 & 69.3 \\
\hline \multirow[t]{3}{*}{ Neck stiffness } & Positive & 51 & 28.5 \\
\hline & negative & 119 & 66.5 \\
\hline & Not documented & 9 & 5 \\
\hline \multirow[t]{4}{*}{ Level of consciousness } & Conscious & 74 & 41.3 \\
\hline & Lethargic & 85 & 47.5 \\
\hline & Semiconscious & 8 & 4.5 \\
\hline & Unconscious & 12 & 6.7 \\
\hline \multirow[t]{3}{*}{ Nerve palsies } & Positive & 19 & 10.6 \\
\hline & Negative & 158 & 88.3 \\
\hline & Yes & 134 & 74.9 \\
\hline \multirow[t]{3}{*}{ Irritability } & No & 45 & 25.1 \\
\hline & Well feeding & 8 & 4.5 \\
\hline & Poorly feeding & 107 & 59.8 \\
\hline \multirow[t]{2}{*}{ Feeding } & Refuse to feed & 64 & 35.8 \\
\hline & Yes & 163 & 91.1 \\
\hline \multirow{2}{*}{ Vomiting } & No & 16 & 8.9 \\
\hline & Yes & 2 & 1.1 \\
\hline Bulged fontanel & No & 177 & 98.9 \\
\hline \multirow[t]{2}{*}{ CSF analysis } & Yes & 125 & 69.8 \\
\hline & No & 54 & 30.2 \\
\hline WBC count both in & $<5000$ cells $/ \mathrm{m} 3$ & 3 & 1.7 \\
\hline \multirow[t]{2}{*}{ blood \& CSF $(\mathrm{n}=125)$} & $5000-10000$ cells $/ \mathrm{m} 3$ & 139 & 91.6 \\
\hline & $>10000$ cells/m3 & 12 & 6.7 \\
\hline \multirow{5}{*}{$\begin{array}{l}\text { Color and condition of } \\
\text { CSF }(n=125) \\
\text { CSF Protein level } \\
(n=125)\end{array}$} & Clear & 86 & 68.8 \\
\hline & Crystal & 39 & 31.2 \\
\hline & $<15 \mathrm{mg} / \mathrm{dl}$ & 1 & 0.8 \\
\hline & $15-50 \mathrm{mg} / \mathrm{dl}$ & 15 & 12 \\
\hline & $>50 \mathrm{mg} / \mathrm{dl}$ & 109 & 87.2 \\
\hline \multirow{3}{*}{ Glucose level of $\operatorname{CSF}(n=125)$} & $<70 \mathrm{mg} / \mathrm{dl}$ & 103 & 82.4 \\
\hline & $70-126 / 200 \mathrm{mg} / \mathrm{dl}$ & 22 & 17.6 \\
\hline & $>126 / 200 \mathrm{mg} / \mathrm{dl}$ & 0 & 0 \\
\hline
\end{tabular}

DOI: http://dx.doi.org/10.4314/ejhs.v28i5.7 
Table 2. continued....

\begin{tabular}{llll}
\hline Gram stain & Yes & 106 & 84.8 \\
\hline done(n=106) & No & 19 & 15.2 \\
Gram stain & Positive & 32 & 30.2 \\
result(n=106) & Negative & 49 & 46.2 \\
& Undifferentiated & 25 & 23.6 \\
AFB done(n=125) & Yes & 48 & 38.4 \\
& No & 77 & 61.6 \\
AFB result(n=48) & Positive & 3 & 6.3 \\
& Negative & 44 & 93.7 \\
Indian Ink test & Yes & 5 & 4 \\
done(n=125) & No & 120 & 96 \\
Indian Ink test & Positive & 1 & 20 \\
result(n=5) & Negative & 4 & 80 \\
Seizure & Yes & 58 & 32.4 \\
& No & 121 & 67.6 \\
Hydrocephalus & Yes & 5 & 2.8 \\
& No & 174 & 97.2 \\
Paralysis & Yes & 1 & 0.6 \\
Brain abscess & No & 176 & 99.4 \\
Shock & Yes & 2 & 1.1 \\
& No & 175 & 98.9 \\
Respiratory distress & Yes & 7 & 3.9 \\
Final outcomes & No & 172 & 96.1 \\
& Yes & 41 & 22.9 \\
& No & 138 & 77.1 \\
& Improved & 136 & 75.9 \\
& Developed complication & 19 & 10.6 \\
& Referred to higher facility & 8 & 4.5 \\
& Died & 6 & 3.4 \\
\hline
\end{tabular}

Clinical presentations, laboratory findings and outcomes of meningitis: Nearly one third of the patients, 58(32.4\%), were worse at presentation. About 64(35.8\%) arrived at the health facilities within 3-7 days of the onset of illness. Form all patients, 55(30.7\%) and 51(28.5\%) were positive for brudzinski's and kernig's sign, respectively. With regard to their level of consciousness, 85(47.5\%) were lethargic. From 179 patients, Cerebrospinal fluid (CSF) analysis was done for 125(69.8\%); among them, 151(98.3\%) developed leukocytosis. Gram stain was done for 106(84.8\%), and most of them, 49(46.2\%), were gram negative.

Most of the study participants, 125(69.8\%) had confirmed meningitis. In most patients, $114(63.7 \%)$ there was no improvement seen with initial antibiotic therapy. Most patients 136
(75.9\%), discharged after improvement. From all patients studied, $10(5.6 \%)$ left the hospital against medical advice, and $3.4 \%$ cases died. Among the total participants of the study, 58(32.4\%) developed seizure. In addition: 5(2.8\%), one $(0.6 \%)$, two (1.1\%), seven (3.9\%) and 41(22.9\%) developed hydrocephalus, paralysis, brain abscess, shock and respiratory distress, respectively (Table 2).

Factors associated with poor outcome of meningitis:To identify factors associated with poo $r$ outcome of meningitis, each variable was assessed independently whether they were predictors of poor outcome or not. First, variables were tested using bivariate analysis. Variables which had $\mathrm{P}<0.25$ were: age, residence, season of admission, immunization status, clinical presentation, oxygen administration, corticosteroid 
administration, gram stain, Acid Fast Bacilli (AFB), Indian ink and co morbidity with HIV.

Variables which were selected in the bivariate analysis were tested in the multivariate analysis to see their significant effect on outcome meningitis. After adjusting for potential con founders in multivariate logistic regression analysis, season of admission, immunization status, clinical presentation and corticosteroid administration remained significant.

Season of admission was significantly associated with clinical outcome meningitis. Children who were admitted in winter season were 5 times higher to have good outcome than those admitted in summer season $[\mathrm{AOR}=5(1.191,20.991)]$. Children's immunization status was also associated with clinical outcome of meningitis.. Patients who completed their immunization were almost 20 times higher to have good outcome than those who didn't complete their vaccination $[\mathrm{AOR}=$ $20.912(3.325,131.502)]$.

Pertaining to clinical presentation, children with worse clinical presentation were almost 9 times more likely to develop poor outcome than those with better presentation $[\mathrm{AOR}=8.779(1.599,48.192)]$. Children who did not received corticosteroid medication were almost 8 times higher to develop poor outcome than those who receive corticosteroid treatment $[\mathrm{AOR}=$ 8.215 (1.220, 55.328)] (Table 3).

Table 3: Distribution of clinical outcome of meningitis patient who were admitted in FHRH, from July 2014-June 2015, Bahir Dar, Ethiopia, 2016 ( $\mathrm{n}=179)$.

\begin{tabular}{|c|c|c|c|c|c|}
\hline \multirow[t]{3}{*}{ Variables } & & \multicolumn{2}{|c|}{ Clinical outcomes } & \multirow{3}{*}{ COR (95\% CL) } & \multirow{3}{*}{$\operatorname{AOR}(95 \% \mathrm{CL})$} \\
\hline & & Good & Poor & & \\
\hline & & $(\mathrm{N} \& \%)$ & $(\mathrm{N} \& \%)$ & & \\
\hline \multirow[t]{2}{*}{$\overline{\text { Age }}$} & Up 1 years & 30 & 19 & $0.357(0.173,0.739)$ & \\
\hline & Above 1 years & 106 & 24 & 1 & \\
\hline \multirow{2}{*}{ Residence } & Urban & 88 & 32 & $1.587(0.735,3.427)$ & \\
\hline & Rural & 48 & 11 & 1 & \\
\hline \multirow{2}{*}{$\begin{array}{l}\text { Season of } \\
\text { admission }\end{array}$} & Winter & 77 & 20 & $0.666(0.335,1.326)$ & $5(1.191,20.991)$ \\
\hline & Summer & 59 & 23 & 1 & 1 \\
\hline \multirow{2}{*}{$\begin{array}{l}\text { Immunization } \\
\text { status }\end{array}$} & Completed & 93 & 16 & $0.103(0.039,0.276)$ & $20.912(3.325,131.502)$ \\
\hline & Not completed & 9 & 15 & 1 & 1 \\
\hline \multirow{2}{*}{$\begin{array}{l}\text { Clinical } \\
\text { presentation }\end{array}$} & Worse & 33 & 25 & 1 & 1 \\
\hline & Not worse & 103 & 18 & $4.335(2.107,8.921)$ & $8.779(1.599,8.192)$ \\
\hline \multirow{2}{*}{$\begin{array}{l}\text { Oxygen } \\
\text { administration }\end{array}$} & Yes & 13 & 15 & $0.197(0.084,0.461)$ & \\
\hline & No & 123 & 28 & 1 & \\
\hline \multirow{2}{*}{$\begin{array}{l}\text { Corticosteroid } \\
\text { administration }\end{array}$} & Yes & 55 & 23 & 1 & 1 \\
\hline & No & 81 & 20 & $1.694(0.849,3.377)$ & $8.215(1.220,55.328)$ \\
\hline \multirow[t]{2}{*}{ Gram stain } & Yes & 85 & 21 & $2.024(0.797,5.139)$ & \\
\hline & No & 18 & 9 & 1 & \\
\hline \multirow[t]{2}{*}{ AFB } & Yes & 68 & 16 & $1.750(0.765,4.001)$ & \\
\hline & No & 34 & 14 & 1 & \\
\hline \multirow[t]{2}{*}{ Indian ink } & Yes & 60 & 14 & $1.633(0.720,3.701)$ & \\
\hline & No & 42 & 16 & 1 & \\
\hline \multirow[t]{2}{*}{ With HIV } & Yes & 3 & 10 & $0.074(0.019,0.268)$ & \\
\hline & No & 133 & 33 & 1 & \\
\hline $\begin{array}{l}\text { DISCUSSION } \\
\text { In this study, } \\
\text { years of age. }\end{array}$ & $\begin{array}{l}\text { leningitis was ce } \\
\text { Jhich was } 34.6^{\circ}\end{array}$ & $\begin{array}{l}\text { mmon bety } \\
\text { and was }\end{array}$ & $\begin{array}{l}\text { een } 5-15 \\
\text { igher in }\end{array}$ & \multicolumn{2}{|c|}{$\begin{array}{l}\text { females }(54.8 \%) \text { than males. A similar study in the } \\
\text { USA showed that being male was reported to increase } \\
\text { the risk of acquiring meningitis }(10) \text {. This may be due } \\
\text { to demographic, socio cultural and economic } \\
\text { differences between countries. }\end{array}$} \\
\hline
\end{tabular}

DOI: http://dx.doi.org/10.4314/ejhs.v28i5.7 
Season of admission was the significant factor for clinical outcome of meningitis. Patients who were admitted in winter season were more likely to develop poor outcome than those admitted in summer season. This may be due to the fact that most patients $(30.2 \%)$ were admitted in winter season. A similar study conducted in Nigeria (11), USA (12,13), Britain (14), Teheran (15) indicated that most meningitis patients were admitted in spring season. The difference may be due to the fact that the location of the country near to sub-Saharan Africa.

In this study, immunization status of children determines the clinical outcome of meningitis. Children who completed their vaccination had better outcome than those who did not complete their vaccination. In this study, 49.4\% children completed their vaccination. A study conducted in the USA, $58 \%$ of meningitis patients were vaccinated against meningitis after the age of 2 years (10), and this finding is similar with other studies (16-20). This could be due the protective effect of vaccines to prevent against major causes of childhood meningitis.

This study shows that the form of clinical presentation of the patients determines the clinical outcome, i.e., children with worse clinical presentation like with seizure and nuchal rigidity developed poor outcome than those with better presentation. This finding is similar with other studies (21-23). This may be due to poor adherence to the treatment, late initiation of antibiotics and lack of proper supportive care like nursing care.

Children who did not receive corticosteroid medication were almost 8 times higher to develop poor outcome than those who received corticosteroid medication. This is similar with other studies conducted in (24-28). This is due to the fact that corticosteroids decreases inflammations, lessens pressure of brain and spread of infections. It decreases associated complications like seizures and hearing loss.

In this study, $32.4 \%$ patients developed seizure, $2.8 \%$ developed hydrocephalus and 1.1\% developed brain abscess. A similar study in Melbourne (18) showed hydrocephalus (12.5\%), cerebral palsy, hemiparesis and paralysis as major neurologic sequelae in children with purulent meningitis, neuromotor disabilities (11.8\%) and hearing loss $(7.6 \%)$ were also substantial. Hearing evaluation should be done at or soon after discharge $(3,29)$. However, in this study, patients were not evaluated for hearing complications.

In conclusion, this study showed that $15 \%$ of pediatrics patients with meningitis developed negative outcomes. Patients who were admitted in winter season, with better clinical presentation, completed their vaccination and managed with corticosteroids had good prognosis than their counter parts. Treating patients with latest and rational use of antibiotics and corticosteroids, creating community awareness about risk factors and early treatment seeking practice, providing appropriate nursing care, improving nutritional status of children and homecare are recommended to improve clinical outcome.

As a limitation, since the study was based on the documented data (chart review) and may not display all factors that were not documented in the patient's files.

\section{ACKNOWLEDGEMENT}

First, we would like to acknowledge Bahir Dar University, College of Medicine and Health Science Department of Nursing, for providing necessary support to conduct this research. We also would like to thank the FHRH administrators and record keepers for their cooperation during data collection process.

\section{REFERENCES}

1. Hung-Ming Wu, Wan-Yu Huang, Meng-Luen Lee, Albert D Yang, Ko-Ping Chaou, and Lin-Yu Hsieh. Clinical features, acute complications, and outcome of Salmonella meningitis in children under one year of age in Taiwan. BMC infectious diseases, 2011;11(1): 30 .

2. Donnell EP, Hurt KM, Scheetz MH, Postelnick MJ, and Scarsi KK: Empiric antibiotic selection for infectious emergencies: bacterial pneumonia, meningitis and sepsis. Drugs Today (Barc). 2009; 45(5):379-393.

3. Grandgirard D, Leib SL. Strategies to prevent neuronal damage in pediatrics bacterial meningitis. Curr Opin Pediatr.2006; 18:112-8.

4. Peltola H and Roine I. Improving the outcomes in children with bacterial meningitis. Current opinion in infectious diseases, 2009;22: 250-255.

5. Davison KL, Ramsay ME.The epidemiology of acute meningitis in children in England and Wales. Arch Dis Child. 2003; 88:662-664.

6. Sharon EM, Facep FA.Acute Bacterial Meningitis. Emerg Med Clin N Am. 2008;(38): 281- 317.

7. Keneuoe HT, Keanole MM, Varsay JLC. Clinical Presentation, etiology, and Outcomes of Meningitis in a Setting of High HIV and TB Prevalence. Journal of tropical medicine, 2015;2015:1-7.

8. Ceyhan M, Yildirim I, Balmer P, Borrow R, Dikici P, Turgut et al.A Prospective Study of Etiology of Childhood Acute Bacterial Meningitis, Turkey. Emerging Infectious Diseases. 2008; 14:7. 
9. Farag HM, Abdel-Fattah MM, Youssri AM. Epidemiological, Clinical and Prognostic Profile of Acute Bacterial Meningitis among Children in Alexandria, Egypt. Indian J Med Microbiol. 2005; 23(2):95-101.

10. Brouwer MC, Tunkel AR, Van de Beek D. Epidemiology, diagnosis, and antimicrobial treatment of acute bacterial meningitis. Clin Microbiol Rev. 2010; 23(3):467-492.

11. Lebel MH, Freij BJ, Syrogiannopoulos GA, Chrane DF, Hoyt MJ, Stewart SM, et al. Dexamethasone therapy for bacterial meningitis. New England Journal of Medicine. 1988;319(15):964-71.

12. Doern GV, Brueggemann A, Holley HP, Rauch AM. Antimicrobial resistance of Streptococcus pneumoniae recovered from outpatients in the United States during the winter months of 1994 to 1995: results of a 30-center national surveillance study. Antimicrobial Agents and Chemotherapy. 1996;40(5):1208-13.

13. Pacheco TR, Cooper CK, Hardy DJ, Betts RF, Bonnez W. Failure of cefotaxime treatment in an adult with Streptococcus pneumoniae meningitis. The American journal of medicine. 1997;102(3):303-5.

14. O'farrell R, Thornton J, Brennan P, Brett F, Cunningham A. Spinal cord infarction and tetraplegia--rare complications of meningococcal meningitis. British journal of anaesthesia. 2000;84(4):514-7.

15. Mosavi-Jarrahi A, Esteghamati A, Asgari F, Heidarnia M, Mousavi-Jarrahi Y, Goya M. Temporal analysis of the incidence of meningitis in the Tehran metropolitan area, 1999-2005. Population health metrics. 2009;7(1):19.

16. Thigpen MC, Whitney CG, Messonnier NE, Zell ER, Lynfield R, Hadler JL, et al. Bacterial meningitis in the United States, 1998-2007. New England Journal of Medicine. 2011;364(21):2016.

17. Sáez-Llorens X, McCracken GH. Bacterial meningitis in children. The lancet. 2003;361(9375):2139-48.

18. Grimwood K, Anderson P, Anderson V, Tan L, Nolan T. Twelve year outcomes following bacterial meningitis: further evidence for persisting effects. Archives of disease in childhood. 2000;83(2):111-6.
19. McIntyre PB, O'Brien KL, Greenwood B, Van De Beek D. Effect of vaccines on bacterial meningitis worldwide. The Lancet. 2012;380(9854):1703-11.

20. Black S, Shinefield H, Fireman B, Lewis E, Ray P, Hansen JR, et al. Efficacy, safety and immunogenicity of heptavalent pneumococcal conjugate vaccine in children. The Pediatric infectious disease journal. 2000;19(3):187-95.

21. Proulx N, Frechette D, Toye B, Chan J, Kravcik S. Delays in the administration of antibiotics are associated with mortality from adult acute bacterial meningitis. Qjm. 2005;98(4):291-8.

22. Miner JR, Heegaard W, Mapes A, Biros M. Presentation, time to antibiotics, and mortality of patients with bacterial meningitis at an urban county medical center. The Journal of emergency medicine. 2001;21(4):387-92.

23. Weisfelt M, van de Beek D, Spanjaard L, Reitsma JB, de Gans J. Clinical features, complications, and outcome in adults with pneumococcal meningitis: a prospective case series. The Lancet Neurology. 2006;5(2):123.

24. Tauber MG, Khayam-Bashi H, Sande MA. Effects of ampicillin and corticosteroids on brain water content, cerebrospinal fluid pressure, and cerebrospinal fluid lactate levels in experimental pneumococcal meningitis. Journal of Infectious Diseases. 1985;151(3):528-34.

25. 25. Prasad K, Singh MB. Corticosteroids for managing tuberculous meningitis. Cochrane Database Syst Rev. 2008;1(1).

26. 26. Odio CM, Faingezicht I, Paris M, et al. The beneficial effects of early dexamethasone administration in infants and children with bacterial meningitis. New England Journal of Medicine. 1991;324(22):1525.

27. Mongelluzzo J, Mohamad Z, Ten Have TR, Shah SS. Corticosteroids and mortality in children with bacterial meningitis. JAMA. 2008;299(17):2048.

28. Brouwer MC, McIntyre P, de Gans J, Prasad K, van de Beek D. Corticosteroids for acute bacterial meningitis. Cochrane Database Syst Rev. 2010;9.

29. Andargachew M, Afework K, Belay T .Bacterial isolates from cerebrospinal fluids and their antibiotic susceptibility patterns in Gondar University Teaching Hospital, Northwest Ethiopia. Ethiop.J.Health Dev. 2005;19(2):160-4. 